\title{
Role of Jordanian Schools in Addressing the Effects of Cultural Globalization
}

\author{
Reem Yousef Saleh \\ Prof. Mohammed Alzbon \\ Department of Educational Management and Foundations, Faculty of Educational Sciences, \\ The University of Jordan, Jordan
}

\begin{abstract}
The phenomenon of globalization and cultural pollution is one of the most sensitive and dangerous issues that Arab world is witnessing today, which negatively affects the behavior of young people and adolescents. The current research seeks to reveal the role of Jordanian schools in addressing the effects of cultural globalization, in addition to revealing the challenges faced by Jordanian schools in dealing with these effects and acknowleging the appropriate school roles for the Jordanian educational system in addressing the effects of cultural pollution among the students of the basic stage in Jordanian schools. In order to achieve the objectives of the research, the descriptive-developmental approach was used. The research was applied to a sample of the primary stage teachers in Jordan.
\end{abstract}

Keywords: Globalization, cultural pollution, Jordan, teachers, schools.

DOI: $10.7176 / \mathrm{JEP} / 10-33-13$

Publication date: November $30^{\text {th }} 2019$

\subsection{Introduction}

Today, the world is experiencing great changes in various fields; such changes have become difficult challenges that are accelerating by time, mainly strength caused by the scientific and technological revolution and the amazing developments in means of communication and information. Despite this progress, prosperity of humanity, it has been accompanied with many problems that have adversely affected individuals and societies, including cultural pollution (Brynjolfsson \& McAfee, 2011).

Moreover, the educational institutions are considered social institutions that play a leading role and a major responsibility in achieving human development in all aspects of life, maintaining self-identity and facing the global community; education throughout the developed world is undergoing changes because of the contemporary technological, informational and civilizational developments. Therefore, the role of the educational systems is to develop positive thinking among individuals, deepen the concept of participation, and promote cultural awareness. Besides building the students' personality more effectively so that they can develop their abilities in a better way, and to know their capabilities and working on developing them, and thus increasing their participation in building their society in a distinctive way (Stewart, 2013).

Schools and educational institutions are of great importance because of their role in protecting individuals, as the integrated educational system is one of the main pillars that contribute to support the homogeneity of the individuals with their society by emphasizing it in the childhood at early stages of education through focusing on a set of values and standards that are compatible with the society, which helps in creating national belonging among its members. Hence the role of the educational systems in preserving individuals and protecting their culture, especially in light of the challenges they face (Al-Sultani, 2015).

The most important challenges facing the Arab culture, including the Jordanian calture too, are the imported ideas and models of the Western philosophy adopted by Arab societies, which is diferent than their cultures and significantly affect their value system and ethics of individuals and groups, this forces communities to adopt procedural measures and precautions to consolidate the foundations of consciousness in order to preserve their cultural uniqueness and to promote awareness based on identity (Sakran, 2016).

Culture and values of individuals is one of the most important aspects that emphasized the importance of the educational systems nowadays, especially in light of the deterioration of the level of individual culture and the poor moral values, not only at the local level, but also at the global level. This is proved by the emergence of many forms of moral and cultural decay, such as suicide attempts and the spread of crime in its worst forms that were not previously recognized by societies. This is a sign of disturbance in social, cultural and ethical norms, and these social, cultural and moral norms are rooted in the individual since childhood (Al-Qadi, Abdulghani \& Noor, 2012).

\subsection{Problem statement}

The Arab world is currently facing a new concept known as globalization, which is represented by different forms, one of the most prominent forms is cultural globalization, which had many positive and negative consequences on individuals and Arab societies. The researchers noticed that their children who are living in 
their community, are affected by cultural globalization phenomenon on their behavior, words, and the use of foreign words and other obvious effects that reflect the adoption and imitation of Western cultures; and these manifestations reflect a new phenomenon called cultural pollution. And by looking at the results of some previous studies related to the subject of this research such as the study of Al-Habashi (2013) and the study of Obeidi (2013), besides the study of Mahmoud and Rahim (2016), which were some of the most important studies that concluded that there is a notable percentage of cultural pollution which cannot be ignored among the people of the Arab world. In addition, there are some deficiencies in the curricula, methods and tools of education and what the school is doing to the face the effects of cultural pollution. Therefore, the researchers have been guided to conduct this research to reveal the role of Jordanian schools in addressing the effects of cultural globalization, which is represented by cultural pollution. Thus, the problem of this research can be represented in the following main question: What is the role of the Jordanian schools in addressing the effects of cultural globalization?

A number of sub-questions emerge from the main question, the most important of which are:

- What are the effects of globalization and cultural pollution on the primary students in Jordan?

- What are the challenges facing the school and that limit the effects of globalization and cultural pollution among students in the primary stage?

\subsection{Study objectives}

This study seeks to reveal the role of Jordanian schools in addressing the effects of cultural globalization among primary school students. In addition to addressing the challenges facing Jordanian schools in dealing with these effects and identifying the appropriate role of the Jordanian educational system in addressing these effects of the cultural pollution among students of the primary stage in the Jordanian schools.

\subsection{Study importance}

The current study draws its importance from its objectives, by addressing the following stakeholders:

- Jordanian schools, as demonstrating the importance of schools in addressing the effects of cultural pollution through a range of tools, including teacher, curriculum and student activities.

- Stakeholders and decision makers, as the outcomes of this research, will be considered as the base on which they can modify and develop the educational foundations of the Jordanian schools, and to activate the role these schools in confronting the effects of cultural pollution.

- The Jordanian family, by highlighting the effects of the cultural pollution on their children and how to educate these families about their roles.

- Researchers and those who are interested in this field, by enriching the literature of this subject.

\subsection{Terminology}

Globalization: One of the most important phenomena associated with the new world order that aims at integration of various fields, making a global effect in this field, and to overcome the international barriers (Holm, 2019).

Culture: The set of the physical, moral, spiritual and emotional features of a society, through which society and its categories can be distinguished from other groups and societies, and it encompasses the lifestyles, systems of values, traditions, and the beliefs practiced by the society that reflect its identity (Masadieh, 2017).

Cultural globalization: It is a global phenomenon represented by the exchange of information, ideas, beliefs, values and cultural traditions in various forms among both societies of developed and developing countries, which generates great knowledge of development, and has both positive and negative effects on societies (Stromquist \& Monkman, 2014).

Cultural pollution: It is the sum of ideas and beliefs adopted by the students of the basic stage and affecting their general behaviors and their general appearance, which differ from the trends, values, customs and traditions adopted by the Arab society (Dürr, 2010).

\subsection{Study limitations}

The study adheres to a combination of the following limits:

- Objective limits: The study is limited to revealing the role of Jordanian schools in addressing the effects of globalization and cultural pollution among the students of the primary stage.

- Spatial limits: The study is limited to the government primary schools in the Directorate of Education for three different areas of Irbid (First Area), Zarqa (II) and Aqaba.

- Human limits: The study is limited to male and female teachers in the primary stage in the directorates of education (Irbid I, Zarqa II and Aqaba).

- $\quad$ Time Limits: The study was conducted during the second semester of the acadmic year 2018/2019. 


\subsection{Literature review}

\subsubsection{The concept of cultural pollution}

Cultural pollution is considered one of the most serious manifestations of globalization that threatens the world now, as this type of pollution affects human souls and destroys personal identity by replacing them with corrupt and false exotic ideas promoted by spoilers and vandals, by displaying behaviors and promoting ideologies claiming to be modern and contemporary (Steger, 2017).

Cultural pollution constitutes the manifestations, behaviors, ideas and beliefs that young people exhibit in their behaviors because of globalization and openness to Western cultures, which are far from the healthy traditions and customs in following cultures other than their cultures, which seek to create a generation that respects its past and faith (Obeidi, 2013).

\subsubsection{Factors of cultural pollution}

There are a number of factors that have led to the passage of Western culture and facilitated its transmission between the developed and developing world, affecting the ideas, values and practices of young people, in a way that leads them away from their original Arab culture. The following are some of the factors behind the manifestations of cultural pollution in the Arab societies:

1. Cultural Variables of this era: As societies witness many successive developments that have contributed to change the cultural patterns prevailing in societies. The development of mass media and communication between communities have had an impact on cultural changes. (Abu Daf \& Al-Agha, 2001).

2. Cultural Invasion of Arab Countries: The Islamic world has been subject in the past to many attacks and cultural invasions, which carried many customs, traditions and values, contrary to the guidance of Arab culture and their ideology, and distorting their customs, traditions and social manifestations.

3. Neglect of family education: The family plays a big role in drawing the culture of individuals, raising them, forming their personalities, and influencing their beliefs directed to various behaviors.It plays the main role in teaching the individual from the earliest age how to control cultural and moral desires and tendencies.

4. Cultural and educational institutions: These institutions are no less important in the cultural upbringing of individuals of communities, so that the educational institutions in the community is an educational platform from which cultural pollution may be driven, as in the case of mass media and cultural invasion. (Qarywa and Hamash, 2016).

\subsubsection{The role of schools in addressing the effects of globalization}

Individuals spend most of their times in schools and institutes, which justifies their great ability to influence their concepts, culture and values, and their ability to shape or destroy thier personalities, through the educational foundations adopted by the national educational systems, philosophy and ideologies, as well as some of its policies that may sometimes aim at cultural alienation of the ideas of its students make them act according to these Western educational foundations and programs. This explains its great ability to spread cultural pollution to individuals, if not the most dangerous and contributing factor causing the spread of the cultural pollution (Kumagai \& Lypson, 2009).

The faculty members and teachers in these schools and institutions have an effective contribution to spreading or responding to cultural pollution through the ideas they give to their pupils and their work to raise the future generations. Students in these institutions take their teachers as role models, following them in thinking and ideologies (Abu Jalala, 2003).

\subsubsection{The role of teachers in facing cultural pollution}

Teachers have a great and effective educational role in building the students' minds, conscience, good behavior, their holistic view of life, interaction with society and respect of their national culture, as teachers are entrusted with the function of protecting students' culture, awareness, attitudes and values, and protecting them from overwhelming fascination with Western thought, and its prevailing cultural trends; through the so-called confrontation of the cultural pollution. Therefore, the community hopes that teachers will be able to do the following, to ensure that they protect the culture of the community and promote its values and preserve their beliefs and values as follows:

- Carrying the burdens of education with high efficiency, quality and proficiency to enable it to face the challenges of the cultural pollution.

- To be well prepared in such a way that it is able to make appropriate plans for the reform and development of the educational system.

- $\quad$ To link the study content with the community issues and problems.

- To show sufficient interest in scientific and applied fields, along with the interest in the cultural and theoretical aspects.

- $\quad$ To have the ability to employ educational and psychological theories, and various academic educational information in the teaching tools and methods. 
1.7.5 The educational roles that must be exercised by the teacher to face the effects of cultural pollution in the educational field

The educational role of the teacher is considered the most important role to face the cultural pollution, as shown by Abu Jalala (2003) and Mahmoud (2017) as follows:

1. Educate students how cultural pollution affect thier educational behavior and beliefs.

2. To clarify to students the objectives of cultural pollution and cultural invasion and the desire of some invaders to underestimate the educational gains of the nation.

3. Raising students' awareness of the risks and damages of the systematic cultural pollution.

4. Activate teachers' role in the formulation of educational curricula directed to institutes and schools.

5. Assist students in the preparation of educational research related to society and strengthen its culture.

6. Helping students to develop self-disciplines of behavior.

1.7.6 The educational roles that must be exercised by the teacher to face the effects of cultural pollution in the social field

The role of teacher in facing the challenges of the cultural pollution in the social field is no less important than other areas, where the teacher is required to guide his students towards finding ways and mechanisms of confrontation at the social level. The following are the most prominent educational roles that must be played by the teacher to face cultural pollution:

1. Raising students' awareness of the cultural pollution in the social aspects.

2. Emphasizing the important role of women in the modern era, as the origin of new generations, and the mediator that conveys the culture of society to those generations.

3. Raising students' awareness of the most important social challenges resulting from cultural pollution, such as the problem of unemployment and poverty.

1.7.7 The educational roles that must be exercised by the teacher to face the effects of cultural pollution in the cultural field

The role of the teacher is also highlighted in the cultural field to face cultural pollution and cultural invasion, so that the culture of any society is the most immune wall that faces the challenges of the cultural pollution:

1. To rebuild and develop the classical Arabic language, through a firm will stemming from a deep conviction that Arabic is a long-standing language representing the cultural heritage of the Arab society.

2. Providing students with a scientific culture, which enables them to acquire a scientific cultural background.

3. Introducing a fourth dimension; the cultural and values dimension, to confirm and develop loyalty among students, which ultimately leads to the achievement of national identity.

1.8 Methods and procedures

1.8.1 Study methodology

To achieve the objective of the study and to answer its questions, a descriptive analytical approach was used, as it is appropriate to the nature of the research.

\subsubsection{Study population}

The study population consisted of 65240 teachers in Jordan, according to the Ministry of Education statistics for the academic year 2018/2019.

\subsubsection{Study sample}

The research sample was selected randomly. Including the Directorate of Education for Irbid (I) Region to represent the north of the Kingdom and the Directorate of Education for Zarqa (II) to represent the Center and the Directorate of Education for Aqaba Region to represent the South.

\subsubsection{Study tool}

The researchers used the questionnaire as the study tool for collecting data in order to meet the study objectives and answering its questions. The questionnaire paragraphs were extracted from the theoretical litreture and the previous studies related to the subject of the study.

The questionnaire consisted of two parts: Part one: That included the personal information of the study sample. The second part included the fields of study. The first area: the effects of cultural pollution, the second area: the role of the educational system in facing the effects of cultural pollution, the third area: the challenges facing the Jordanian educational system in facing the effects of cultural pollution, where the paragraphs of all areas are (61) paragraphs. It is also understood that Likert scale is not limited to five categories of answers only, however, in the present study, providing five choices was believed to be the most appropriate situation as shown in the table (1): 
Table (1): The distribution of response options in the questionnaire according to the five-point Likert scale

\begin{tabular}{|l|c|}
\hline \multicolumn{1}{|c|}{ Option } & Class \\
\hline Strongly Agree & 5 \\
\hline Agree & 4 \\
\hline NA & 3 \\
\hline Disagree & 2 \\
\hline Strongly Disagree & 1 \\
\hline
\end{tabular}

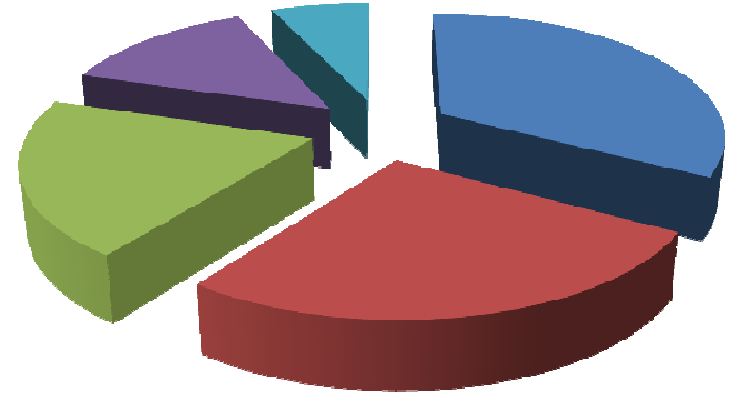

- Strongly Agree

Agree

NA

Disagree

Strongly Disagree

Figure (1): Graphic distribution of the response options in the questionnaire according to the five-point Likert scale

In addition, the following classification was used to judge the arthmetic means as follows:

- $\quad$ Less than 2.33 is low.

- $\quad$ From 2.34 to 3.66 is medium.

- $\quad$ From 3.67 to 5.00 is high.

1.8.4.1 Validity of the study tool

The researchers have verified the external validity of the study tool by presenting it to a group of arbitrators and taking their observations and amendments into consideration, in terms of knowing the validity of language drafting, and the affiliation of the paragraph to the area under which it falls, and the appropriateness and compatibility of the paragraphs with the field of study. In addition, based on the consensus of the arbitrators paragraphs were added or deleted.

\subsubsection{Questionnaire Reliability}

For ensuring the Reliability of the study tool, the researcher used the internal consistency coefficient $(\alpha)$ according to the alpha Cronbach's equation, and the value of $(\alpha) 84.6 \%$, which is high when compared with the minimum acceptable of $60 \%$.

Table (2): Results of the alpha Cronbach's Reliability for the dependent and independent variables

\begin{tabular}{|l|c|c|}
\hline \multicolumn{1}{|c|}{ Variable } & $\begin{array}{c}\text { Reliability } \\
\text { Coefficient }\end{array}$ & Rate \\
\hline The role of the educational system & 90.4 & Good \\
\hline The effects of cultural pollution & 84.5 & Good \\
\hline Challenges facing the educational system & 79.1 & Good \\
\hline Average & 84.6 & Good \\
\hline
\end{tabular}

\subsection{Study Results}

\subsubsection{Results of the main question}

To answer the main question (What is the role of the Jordanian schools in addressing the effects of cultural globalization?) arithmetic means and standard deviations of the role of the Jordanian schools in addressing the effects of cultural globalization were extracted in its various fields (teacher, school administration, topics, school activities) as illustrated in table (3).

Table (3): Arithmetic means and standard deviations of the areas of the role of Jordanian schools in addressing the effects of cultural globalization, arranged by the arithmetic means

\begin{tabular}{|c|l|c|c|c|c|}
\hline No. & \multicolumn{1}{|c|}{ Filed } & Arithmetic mean & Standard deviation & Rank & Degree \\
\hline 1 & Teacher & 3.56 & 0.897 & 2 & Medium \\
\hline 2 & School administration & 3.55 & 0.977 & 3 & Medium \\
\hline 3 & Topics & 3.61 & 0.995 & 1 & Medium \\
\hline 4 & School activities & 3.49 & 1.032 & 4 & Medium \\
\hline \multicolumn{2}{|c|}{ Average } & 3.55 & 0.691 & & Medium \\
\hline
\end{tabular}

Table (3) shows that the arithmetic means ranged between (3.49-3.61), with the higher mean for the field of (topics), with an average of (3.61) which is a medium degree, followed by second place "teacher" with an 
average of (3.56) which is a medium degree. And in the last level, the field of "school activities" with an average of (3.49) which is medium, and the average of the tool as a whole is (3.55), which is medium. Moreover, the following tables show the means and the standard deviations of the study sample on the paragraphs of each field:

\subsubsection{The first field: Teacher}

Table (4): Arithmetic means and standard deviations of paragraphs of the teacher field arranged by arithmetic means $(\mathrm{n}=500)$

\begin{tabular}{|c|c|c|c|c|c|}
\hline No. & Paragraph & $\begin{array}{l}\text { Arithmetic } \\
\text { mean }\end{array}$ & $\begin{array}{l}\text { Standard } \\
\text { deviation }\end{array}$ & Rank & Degree \\
\hline 1 & $\begin{array}{l}\text { Making sure that the teacher understands the dimensions of } \\
\text { the adopted educational vision }\end{array}$ & 3.57 & 1.107 & 5 & Medium \\
\hline 2 & $\begin{array}{l}\text { Teacher's interest in delaying the training of cultural } \\
\text { influences approved by the community }\end{array}$ & 3.55 & 1.300 & 6 & Medium \\
\hline 3 & $\begin{array}{l}\text { Teacher's awareness of the need to link what he offers } \\
\text { students with the cultural dimensions of the society }\end{array}$ & 3.11 & 1.380 & 10 & Medium \\
\hline 4 & $\begin{array}{l}\text { Enhance the teacher's skill by paying attention to relevant } \\
\text { cultural frameworks in the curriculum }\end{array}$ & 3.44 & 1.325 & 9 & Medium \\
\hline 5 & $\begin{array}{l}\text { Encourage students to practice reflexology to ensure that } \\
\text { cultural penetration attempts are ineffective }\end{array}$ & 3.50 & 1.454 & 7 & Medium \\
\hline 6 & $\begin{array}{l}\text { Provides an educational strategy to deal with the cultural } \\
\text { dimensions of the society }\end{array}$ & 3.77 & 1.346 & 2 & High \\
\hline 7 & $\begin{array}{l}\text { Attention to attracting human inputs distinctive } \\
\text { understanding of community living culture }\end{array}$ & 3.89 & 1.335 & 1 & High \\
\hline 8 & $\begin{array}{l}\text { Emphasizing the necessity of the teacher's interest in } \\
\text { combining the teaching process and linking it with the } \\
\text { dimensions of community issues }\end{array}$ & 3.75 & 1.402 & 3 & High \\
\hline 9 & $\begin{array}{l}\text { Comprehensiveness of the teacher's interest in linking the } \\
\text { teaching process, explaining its relationship with the } \\
\text { dimensions of society (economic, political, and cultural) }\end{array}$ & 3.58 & 1.381 & 4 & Medium \\
\hline 10 & $\begin{array}{l}\text { Ensuring the relevance of the cultural variable experienced } \\
\text { by the teacher's mind }\end{array}$ & 3.46 & 1.376 & 8 & Medium \\
\hline \multicolumn{2}{|r|}{ General average } & 3.56 & 0.897 & & Medium \\
\hline
\end{tabular}

Table (4) shows that the arithmetic means ranged between (3.11-3.89), where paragraph (7) which states (Attention to attracting human inputs distinctive understanding of community living culture) ranked first with a high degree. And paragraph (6), which states (Provides an educational strategy to deal with the cultural dimensions of the society) came in the second rank with a mean of (3.77) which is high, while paragraph (8) wich states (Emphasizing the necessity of the teacher's interest in combining the teaching process and linking it with the dimensions of community issues) came in the third rank with the arithmetic mean of (3.75) which is high. And the last rank came paragraph (3) which states (Teacher's awareness of the need to link what he offers students with the cultural dimensions of the society) with a medium degree, and the arithmetic mean of the field as a whole is (3.56) which is of a medium degree. 


\subsubsection{The second field: School administration}

Table (5): Arithmetic means and standard deviations of paragraphs of the school administration field arranged by arithmetic means $(\mathrm{n}=500)$

\begin{tabular}{|c|c|c|c|c|c|}
\hline No. & Paragraph & $\begin{array}{l}\text { Arithmetic } \\
\text { mean }\end{array}$ & $\begin{array}{l}\text { Standard } \\
\text { deviation }\end{array}$ & Rank & Degree \\
\hline 1 & $\begin{array}{l}\text { Strengthen the relationship between school and parents } \\
\text { in all matters relating to the culture of their children }\end{array}$ & 3.28 & 1.389 & 8 & Medium \\
\hline 2 & $\begin{array}{l}\text { Allocate the necessary funds from the school budget to } \\
\text { support cultural activity in the school }\end{array}$ & 3.33 & 1.392 & 7 & Medium \\
\hline 3 & $\begin{array}{l}\text { Designing student activities that contribute to their } \\
\text { cultural awareness }\end{array}$ & 3.23 & 1.424 & 9 & Medium \\
\hline 4 & $\begin{array}{l}\text { Designing programs to promote teacher awareness of } \\
\text { community cultures }\end{array}$ & 3.11 & 1.467 & 10 & Medium \\
\hline 5 & $\begin{array}{l}\text { Emphasis on cultural dialogue between all human } \\
\text { inputs in the school }\end{array}$ & 3.58 & 1.428 & 5 & Medium \\
\hline 6 & $\begin{array}{l}\text { Provide administrative support for everything that } \\
\text { would serve the cultural variable in the school }\end{array}$ & 3.75 & 1.573 & 4 & High \\
\hline 7 & $\begin{array}{l}\text { Adoption of a cultural variable in all school practices } \\
\text { (planning, organization, coordination and evaluation) }\end{array}$ & 3.50 & 1.410 & 6 & Medium \\
\hline 8 & $\begin{array}{l}\text { Diversify activities directed at the school to serve the } \\
\text { promotion of the cultural variable of the society }\end{array}$ & 3.94 & 1.324 & 1 & High \\
\hline 9 & $\begin{array}{l}\text { Provides a deliberate plan related to the media variable } \\
\text { practiced by the school by taking care of its cultural } \\
\text { implications }\end{array}$ & 3.87 & 1.285 & 3 & High \\
\hline 10 & $\begin{array}{l}\text { Ensure that the curriculum takes into consideration the } \\
\text { culture of the community }\end{array}$ & 3.93 & 1.371 & 2 & High \\
\hline \multicolumn{2}{|r|}{ General average } & 3.55 & 0.977 & & Medium \\
\hline
\end{tabular}

Table (5) shows that the arithmetic means ranged between (3.11-3.94), where paragraph (8) which states (Diversify activities directed at the school to serve the promotion of the cultural variable of the society) ranked first with a high degree. And paragraph (10), which states (Ensure that the curriculum takes into consideration the culture of the community) came in the second rank with a mean of (3.93) which is high, while paragraph (9) wich states (Provides a deliberate plan related to the media variable practiced by the school by taking care of its cultural implications) came in the third rank with the arithmetic mean of (3.87) which is high. And the last rank came paragraph (4) which states (Designing programs to promote teacher awareness of community cultures) with a medium degree, and the arithmetic mean of the field as a whole is (3.55) which is of a medium degree.

\subsubsection{The third field: Topics}

Table (6): Arithmetic means and standard deviations of paragraphs of the topics field arranged by arithmetic means $(\mathrm{n}=500)$

\begin{tabular}{|c|c|c|c|c|c|}
\hline No. & Paragraph & $\begin{array}{l}\text { Arithmetic } \\
\text { mean }\end{array}$ & $\begin{array}{l}\text { Standard } \\
\text { deviation }\end{array}$ & Rank & Degree \\
\hline 1 & $\begin{array}{l}\text { Provides a mechanism for participatory evaluation of all } \\
\text { educational practices within the school to ensure that } \\
\text { they are consistent with the adopted culture of the } \\
\text { community }\end{array}$ & 3.80 & 1.346 & 2 & High \\
\hline 2 & $\begin{array}{l}\text { Stressing the need to achieve harmony between the } \\
\text { curricula active in the school and the aspirations of those } \\
\text { responsible at the center }\end{array}$ & 3.82 & 1.318 & 1 & High \\
\hline 3 & $\begin{array}{l}\text { Provide school curricula for margins that allow teachers } \\
\text { to achieve their cultural fingerprints }\end{array}$ & 3.48 & 1.371 & 3 & Medium \\
\hline 4 & $\begin{array}{l}\text { Taking into account the cultural dimensions of society in } \\
\text { the process of curriculum development }\end{array}$ & 3.48 & 1.381 & 3 & Medium \\
\hline 5 & $\begin{array}{l}\text { Designing educational programs in harmony with the } \\
\text { rhyme requirements that serve the local community }\end{array}$ & 3.44 & 1.397 & 5 & Medium \\
\hline & General average & 3.61 & 0.995 & & Medium \\
\hline
\end{tabular}

Table (6) shows that the arithmetic means ranged between (3.44-3.82), where paragraph (2) which states (Stressing the need to achieve harmony between the curricula active in the school and the aspirations of those responsible at the center) ranked first with a high degree. And paragraph (1), which states (Provides a mechanism for participatory evaluation of all educational practices within the school to ensure that they are 
consistent with the adopted culture of the community) came in the second rank with a mean of (3.80) which is high, while paragraphs ( 3 and 4 ) wich states (Provide school curricula for margins that allow teachers to achieve their cultural fingerprints), (Taking into account the cultural dimensions of society in the process of curriculum development) came in the third rank with the arithmetic mean of (3.48) which is medium. And the last rank came paragraph (5) which states (Designing educational programs in harmony with the rhyme requirements that serve the local community) with a medium degree, and the arithmetic mean of the field as a whole is (3.61) which is of a medium degree.

\subsubsection{The fourth field: School activities}

Table (7): Arithmetic means and standard deviations of paragraphs of the school activities field arranged by arithmetic means $(\mathrm{n}=500)$

\begin{tabular}{|c|l|c|c|c|c|}
\hline No. & \multicolumn{1}{|c|}{ Paragraph } & $\begin{array}{c}\text { Arithmetic } \\
\text { mean }\end{array}$ & $\begin{array}{c}\text { Standard } \\
\text { deviation }\end{array}$ & Rank & Degree \\
\hline 1 & $\begin{array}{l}\text { Ensure that all the targeted activities undertaken by the } \\
\text { school promote the positive aspects of the cultural } \\
\text { variable of the community }\end{array}$ & 3.28 & 1.428 & 7 & Medium \\
\hline 2 & $\begin{array}{l}\text { The school is keen to design targeted activities that } \\
\text { promote community culture }\end{array}$ & 3.46 & 1.407 & 3 & Medium \\
\hline 3 & $\begin{array}{l}\text { Enhance the role of the teacher in interacting with his } \\
\text { students to serve the cultural variable }\end{array}$ & 3.84 & 1.348 & 1 & High \\
\hline 4 & $\begin{array}{l}\text { Provide an academic approach that facilitates the } \\
\text { process of cultural assessment of students }\end{array}$ & 3.53 & 1.451 & 2 & Medium \\
\hline 5 & $\begin{array}{l}\text { Interest in research to serve the cultural variable } \\
\text { experienced by the school }\end{array}$ & 3.46 & 1.433 & Medium \\
\hline 6 & $\begin{array}{l}\text { Cultural communication within the school in order to } \\
\text { promote belonging to the culture of the community }\end{array}$ & 3.44 & 1.403 & 5 & Medium \\
\hline 7 & $\begin{array}{l}\text { Provides feedback programs that enable the } \\
\text { continuation of the cultural change experienced by } \\
\text { students }\end{array}$ & 3.38 & 6 & Medium \\
\hline
\end{tabular}

Table (7) shows that the arithmetic means ranged between (3.28-3.84), where paragraph (3) which states

(Enhance the role of the teacher in interacting with his students to serve the cultural variable) ranked first with a high degree. And paragraph (4), which states (Provide an academic approach that facilitates the process of cultural assessment of students) came in the second rank with a mean of (3.53) which is medium, while paragraphs ( 2 and 5) wich states (The school is keen to design targeted activities that promote community culture), (Interest in research to serve the cultural variable experienced by the school) came in the third rank with the arithmetic mean of (3.46) which is medium. And the last rank came paragraph (1) which states (Ensure that all the targeted activities undertaken by the school promote the positive aspects of the cultural variable of the community) with a medium degree, and the arithmetic mean of the field as a whole is (3.49) which is of a medium degree.

\subsubsection{Results for the first question}

To answer the first question, the arithmetic averages and standard deviations were extracted for all paragraphs of the effects of cultural pollution among the students of the primary stage, and table (8) shows that. 
Table (8): Arithmetic means and standard deviations of the effects of globalization and cultural pollution on students of the primary stage arranged by arithmetic means

\begin{tabular}{|c|l|c|c|c|c|}
\hline No. & \multicolumn{1}{|c|}{ Paragraph } & $\begin{array}{c}\text { Arithmetic } \\
\text { mean }\end{array}$ & $\begin{array}{c}\text { Standard } \\
\text { deviation }\end{array}$ & Rank & Degree \\
\hline 1 & Impact on the system (values, attitudes and feelings) & 4.08 & 1.113 & 1 & High \\
\hline 2 & $\begin{array}{l}\text { Focus on the surface of cultural data without seeing } \\
\text { the valuable background on which it is based }\end{array}$ & 3.32 & 1.336 & 9 & Medium \\
\hline 3 & $\begin{array}{l}\text { Lack of insight into the hidden agenda of the specific } \\
\text { cultural aspect }\end{array}$ & 3.65 & 1.258 & 5 & Medium \\
\hline 4 & $\begin{array}{l}\text { Disruption of the ability of society to see the } \\
\text { requirements of comprehensive development }\end{array}$ & 3.64 & 1.202 & 6 & Medium \\
\hline 5 & $\begin{array}{l}\text { Impact on the ability of society to see the } \\
\text { requirements of comprehensive development }\end{array}$ & 3.76 & 1.125 & 3 & High \\
\hline 6 & $\begin{array}{l}\text { Leaking cultural references do not harmonize with the } \\
\text { culture of the nation }\end{array}$ & 3.89 & 1.130 & 2 & High \\
\hline 7 & $\begin{array}{l}\text { Disturb the convictions of individuals with their } \\
\text { cultural heritage }\end{array}$ & 3.31 & 1.299 & Medium \\
\hline 8 & $\begin{array}{l}\text { Leaking of cultural data affecting the integrity of the } \\
\text { prevailing cultural factor }\end{array}$ & 3.34 & 1.280 & 8 & Medium \\
\hline 9 & $\begin{array}{l}\text { Contribute to the process of Westernization of the } \\
\text { original Arab culture }\end{array}$ & 3.54 & 1.178 & 4 & High \\
\hline 10 & $\begin{array}{l}\text { Impact on the value system of passive community } \\
\text { members }\end{array}$ & 3.68 & 3.62 & 0.792 & Medium \\
\hline
\end{tabular}

Table (8) shows that the arithmetic means ranged between (3.31-4.08), where paragraph (1) which states (Impact on the system (values, attitudes and feelings)) ranked first with a high degree. And paragraph (5), which states (Impact on the ability of society to see the requirements of comprehensive development) came in the second rank with a mean of (3.89) which is high, while paragraphs (6) wich states (Leaking cultural references do not harmonize with the culture of the nation) came in the third rank with the arithmetic mean of (3.65) which is medium. And the last rank came paragraph (7) which states (Disturb the convictions of individuals with their cultural heritage) with a medium degree, and the arithmetic mean of the field as a whole is (3.62) which is of a medium degree.

\subsubsection{Results for the second question}

To answer the second question, the arithmetic averages and standard deviations were extracted for all paragraphs of the the challenges facing the school and limit the effects of globalization and cultural pollution among students in the primary stage, and table (9) shows that. 
Table (9): Arithmetic means and standard deviations of the the challenges facing the school and limit the effects of globalization and cultural pollution among students in the primary stage arranged by arithmetic means

\begin{tabular}{|c|c|c|c|c|c|}
\hline No. & Paragraph & $\begin{array}{l}\text { Arithmetic } \\
\text { mean }\end{array}$ & $\begin{array}{l}\text { Standard } \\
\text { deviation }\end{array}$ & Rank & Degree \\
\hline 1 & $\begin{array}{l}\text { Poor language of dialogue among students themselves } \\
\text { especially with regard to social issues }\end{array}$ & 3.02 & 1.384 & 18 & Medium \\
\hline 2 & The intellectual shallowness experienced by most students & 3.58 & 1.298 & 8 & Medium \\
\hline 3 & $\begin{array}{l}\text { Neglecting school curricula to deal with societal cultural } \\
\text { data }\end{array}$ & 3.43 & 1.465 & 13 & Medium \\
\hline 4 & $\begin{array}{l}\text { Lack of awareness of workers in educational institutions } \\
\text { the need for their interest in dealing with the cultural } \\
\text { variable }\end{array}$ & 3.59 & 1.322 & 6 & Medium \\
\hline 5 & $\begin{array}{l}\text { The widening of the cultural gap among members of } \\
\text { Jordanian society }\end{array}$ & 3.53 & 1.320 & 10 & Medium \\
\hline 6 & $\begin{array}{l}\text { Neglecting to benefit of the system of faith values in the } \\
\text { promotion of societal cultural variable }\end{array}$ & 3.61 & 1.387 & 5 & Medium \\
\hline 7 & $\begin{array}{l}\text { Formation of interest in the system of values experienced } \\
\text { by society }\end{array}$ & 3.59 & 1.229 & 6 & Medium \\
\hline 8 & $\begin{array}{l}\text { Lack of attention to the humanization of interaction } \\
\text { between human inputs coexisting in the educational system }\end{array}$ & 3.66 & 1.286 & 3 & Medium \\
\hline 9 & $\begin{array}{l}\text { The manifestations of frustration experienced by some } \\
\text { workers in the educational system, which negatively } \\
\text { affects the requirements of dealing with the fundamentals } \\
\text { of living culture }\end{array}$ & 3.88 & 1.257 & 1 & High \\
\hline 10 & The negative impact of mass communication & 3.64 & 1.312 & 4 & Medium \\
\hline 11 & $\begin{array}{l}\text { The absence of the family's culturally changing interest for } \\
\text { its children }\end{array}$ & 3.57 & 1.283 & 9 & Medium \\
\hline 12 & $\begin{array}{l}\text { Lack of keeping up with the educational thought and the } \\
\text { ever-emerging cultural data }\end{array}$ & 2.97 & 1.405 & 19 & Medium \\
\hline 13 & $\begin{array}{l}\text { Cruelty in dealing with data of cultural originality and } \\
\text { cultural substitutes }\end{array}$ & 3.53 & 1.301 & 10 & Medium \\
\hline 14 & $\begin{array}{l}\text { Lack of interest in dealing with psychological requirements } \\
\text { and benefit from them in the cultural awareness of students }\end{array}$ & 3.03 & 1.391 & 17 & Medium \\
\hline 15 & $\begin{array}{l}\text { Lack of clarity in the dimensions of the value system living } \\
\text { and linking them with teaching skills }\end{array}$ & 3.76 & 1.283 & 2 & High \\
\hline 16 & $\begin{array}{l}\text { Lack of a database that serves to promote the cultural } \\
\text { variable in the process of school education }\end{array}$ & 3.46 & 1.408 & 12 & Medium \\
\hline 17 & $\begin{array}{l}\text { Imbalance in dealing with the dimensions of authenticity } \\
\text { and contemporary cultural community }\end{array}$ & 3.40 & 1.247 & 14 & Medium \\
\hline 18 & $\begin{array}{l}\text { Lack of interest in teaching plans in promoting the societal } \\
\text { cultural variable }\end{array}$ & 3.08 & 1.211 & 16 & Medium \\
\hline 19 & $\begin{array}{l}\text { Lack of seriousness in dealing with manifestations of } \\
\text { cultural distortion }\end{array}$ & 3.27 & 1.116 & 15 & Medium \\
\hline \multicolumn{2}{|r|}{ General average } & 3.45 & 0.601 & & Medium \\
\hline
\end{tabular}

Table (9) shows that the arithmetic means ranged between (2.97-3.88), where paragraph (9) which states (The manifestations of frustration experienced by some workers in the educational system, which negatively affects the requirements of dealing with the fundamentals of living culture) ranked first with a high degree. And paragraph (15), which states (Lack of clarity in the dimensions of the value system living and linking them with teaching skills) came in the second rank with a mean of (3.76) which is high, while paragraph (8) wich states (Lack of attention to the humanization of interaction between human inputs coexisting in the educational system) came in the third rank with the arithmetic mean of (3.66) which is medium. And the last rank came paragraph (12) which states (Lack of keeping up with the educational thought and the ever-emerging cultural data) with a medium degree, and the arithmetic mean of the field as a whole is (3.45) which is of a medium degree.

\subsection{Conclusion}

The results showed that there are effects of globalization and cultural pollution on the primery stage students in Jordan, and this result can be explained by the fact that globalization is widespread among students and is 
incompatible with the culture of the Arab nation by influencing their religious and social values and attitudes. Globalization has influenced educational systems with new requirements and desires for students' ability to transfer education and teachers, rather than bifurcated systems in terms of academic levels, credentials, curricula and assessment, as well as the privatization of education. Despite the importance of addressing the effects of globalization and cultural pollution in general, there is no real commitment in facing them on all employees in the Jordanian schools.

\subsection{Recommendations}

Based on the findings of this study, the researchers recommends the following:

1. Work to reformulate education in the Jordanian schools as that young people need, not only to accept globalization but also to interact with it independently.

2. The necessity of the interaction of workers in the educational system with globalization and the interaction with it purposefully, and prepare the students to respond to the challenges of globalization.

3. Provide students with the knowledge, skills and new values necessary to be able to face the effects of globalization and cultural pollution in the future.

4. Review the components of the teaching process to keep abreast of recent global developments, and develop a cultural strategy with clear objectives.

5. Pay more attention to schools and reduce cultural corruption and globalization through the renewal and consolidation of community culture.

\section{References}

Abu Daf, Mahmoud, and Agha, Mohammed (2001). Cultural pollution among youth in Palestinian society and the role of education in confronting it. Journal of the Islamic University, 9 (2), 58-108.

Abu Jalala, Lamia Mustafa Hassan (2003). The educational role of the university faculty members in facing the challenges of globalization and the ways to develop it from their point of view. Master Degree in Fundamentals of Education, Islamic University, Gaza.

Al-Qadi, Hanan and Abdul Ghani, Qamar and Noor, Mohammed Jie (2012). The teacher's contribution to the social values of ninth grade students. Journal of Arab and Islamic Education, 4 (2), 71-76.

Al-Sultani, Nisreen (2015). The role of education in fortifying the minds emerging from extremism and terrorism. Journal of the Faculty of Basic Education for Educational and Islamic Sciences / University of Babylon, (23), 571-575.

Brynjolfsson, E., \& McAfee, A. (2011). Race against the machine: How the digital revolution is accelerating innovation, driving productivity, and irreversibly transforming employment and the economy. Brynjolfsson and McAfee.

Dürr, E. (2010). Tidy Kiwis, Dirty Asians: Cultural Pollution and Migration in Auckland, New Zealand. Urban pollution: Cultural meanings, social practices, 30-56.

Holm, H. H. (2019). Whose world order?: uneven globalization and the end of the cold war. Routledge.

Kumagai, A. K., \& Lypson, M. L. (2009). Beyond cultural competence: critical consciousness, social justice, and multicultural education. Academic medicine, 84(6), 782-787.

Mahmoud, Aysam Saad (2017). Strengthening the Arab Cultural Identity in Foreign Education Schools: An Empirical Study. Journal of Educational Sciences, 4 (1), 46-123.

Masadieh, Lazhar (2017). In the concept of culture and some of its components: (customs, traditions). Journal of Memory, 9 (1), 33--41.

Obeidi, Afra Ibrahim Khalil Ismail (2013). Cultural pollution and its relationship to the family climate among a sample of university students. Journal of Human Sciences and Society, (7). 75-101.

Qarywa, Zainab, and Hamash, Lamine (2016). Identification fortification bets in light of the invasion of cultural globalization: a field study according to Socio's cultural approach to a sample of university professors. Journal of Humanities, 6, 89-100.

Sakran, Muhammad Muhammad (2016). Education and Cultural Pollution: A Critical Analytical Vision. Journal of the Modern Education Association, 8 (27), 15-27.

Steger, M. B. (2017). Globalization: A very short introduction (Vol. 86). Oxford University Press.

Stewart, F. (2013). Capabilities and Human Development: Beyond the individual-the critical role of social institutions and social competencies. UNDP-HDRO Occasional Papers, (2013/03).

Stromquist, N. P., \& Monkman, K. (Eds.). (2014). Globalization and education: Integration and contestation across cultures. R\&L Education.

Watfa, Ali Asaad, and Ansari, Isa Mohammed (2003). Arab Educational Goals: A Critical Analytical Study. Damascus University Journal, 12 (1), 84--140. 